\title{
Hodgkin's disease following mycosis fungoides: phenotypic and molecular evidence for different tumour cell clones
}

\author{
P Brousset, L Lamant, R Viraben, D Schlaifer, B Gorguet, P Duhault, G Delsol
}

\begin{abstract}
Aims-(1) To assess the clonality of tumour cells in two patients with mycosis fungoides who subsequently developed Hodgkin's disease; and (2) to determine whether there is a clonal relation between these two disorders.

Methods-Cutaneous tissue samples involved by mycosis fungoides and lymph nodes involved by Hodgkin's disease from both patients were investigated by immunohistochemistry and the polymerase chain reaction.

Results-Mycosis fungoides tumour cells in both patients expressed multiple $T$ cell associated antigens; Reed-Sternberg (RS) cells had the null phenotype. $T$ cell receptor $\gamma$ chain genes were clonally rearranged in mycosis fungoides cells but not in RS cells, including variants, in both patients. In the patient with intermediate transformation to large cell lymphoma, immunoglobulin heavy chain genes were rearranged in the cutaneous tumour, but not in the lymph node involved by Hodgkin's disease.

Conclusion-The divergent antigen expression and gene rearrangements observed in these two patients strongly suggest that Hodgkin's disease and mycosis fungoides are not derived from a single tumour cell clone.
\end{abstract}

(F Clin Pathol 1996;49:504-507)

Keywords: mycosis fungoides, Hodgkin's disease, clonality, immunohistochemistry, PCR.

Department of Pathology, CHU Purpan,

Toulouse, France

P Brousset

L Lamant

B Gorguet

G Delsol

Department of Dermatology

R Viraben

P Duhault

Department of Hematology

D Schlaifer

Correspondence to: Dr Pierre Brousset, Laboratoire d'Anatomie Pathologique, Centre Hospitalier de Purpan 31059 Toulouse Cédex, France.

Accepted for publication 1 February 1996 and Hodgkin's disease was first reported in 1963. ${ }^{1}$ Mycosis fungoides lesions usually appear before those of Hodgkin's disease, ${ }^{2}{ }^{3}$ but the reverse has been also documented. ${ }^{4}$ In patients with mycosis fungoides who subsequently develop Hodgkin's disease, the latter is regarded, clinically and histologically, as a second neoplasm as there is no clear biological link between these conditions. ${ }^{3}$ However, the relative high frequency of their association has led some authors to speculate that mycosis fungoides and Hodgkin's disease are derived from the same clone. Kadin ${ }^{5}$ suggested that there is a common, activated $T$ cell clone for lymphomatoid papulosis, mycosis fungoides and Hodgkin's disease. Some support for Kadin's postulate was provided by Davis et al who demonstrated that three different tumours-lymphomatoid papulosis, cutaneous $T$ cell lymphoma and Hodgkin's diseaseoccurring in the same patient, were derived from a single tumour cell clone. To determine whether mycosis fungoides and Hodgkin's disease are indeed derived from the same clone, we assessed the clonality of tumour cells in two patients with mycosis fungoides who subsequently developed Hodgkin's disease.

\section{Methods}

CASE REPORTS

Case 1

A 47 year old white man was first diagnosed with mycosis fungoides in 1983 on examination of a biopsy specimen of a cutaneous plaque. The patient's condition deteriorated despite treatment and in 1985, Hodgkin's disease (stage I) was diagnosed on examination of an enlarged cervical lymph node. The patient went on to develop cutaneous large cell lymphoma (LCL) in 1989 (diagnosed by biopsy), and experienced relapses in 1990 and 1992. The patient underwent biopsy at each relapse. In 1994, the patient relapsed with Hodgkin's disease. At present, the patient is terminally ill, with massive cutaneous tumours.

\section{Case 2}

A 60 year old white man developed cutaneous lesions in 1984 and was diagnosed as having mycosis fungoides. The patient subsequently developed Hodgkin's disease in 1992, while being treated for recurrent mycosis fungoides. Recurrent Hodgkin's disease was confirmed histologically in 1993. A cutaneous plaque was biopsied in 1994 to confirm recurrent mycosis fungoides. The patient is currently alive with disease.
TISSUE SAMPLES

Routinely processed tissue and cryopreserved biopsy specimens of LCL (1989), mycosis fungoides (1994) and Hodgkin's disease (1994) were available for case 1. Cryopreserved biopsy specimens of Hodgkin's disease (1992) and mycosis fungoides (1994) were available for case 2 . A portion of the lymph node biopsy specimen from case 2 was also processed using a modification of the AMeX method (cold acetone fixation, followed by treatment with methyl benzoate and xylene with subsequent routine embedding in paraffin wax) as reported by Delsol et al. ${ }^{7}$ This modified method (ModAMeX) involves the use of proteolytic enzyme inhibitors and low temperature embedding in paraffin wax, resulting in better 


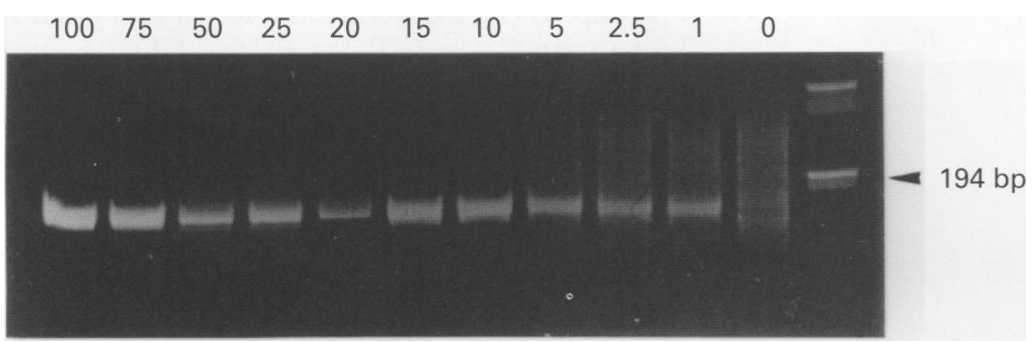

Figure 1 Dilutions of DNA from the HSB2 T lymphoma cell line in polyclonal DNA from normal blood lymphocytes. The lowest level of detection with the $\gamma 2$ primer set was about $1 \%$. Note that the polyclonal background signal increases as the target DNA becomes more dilute.

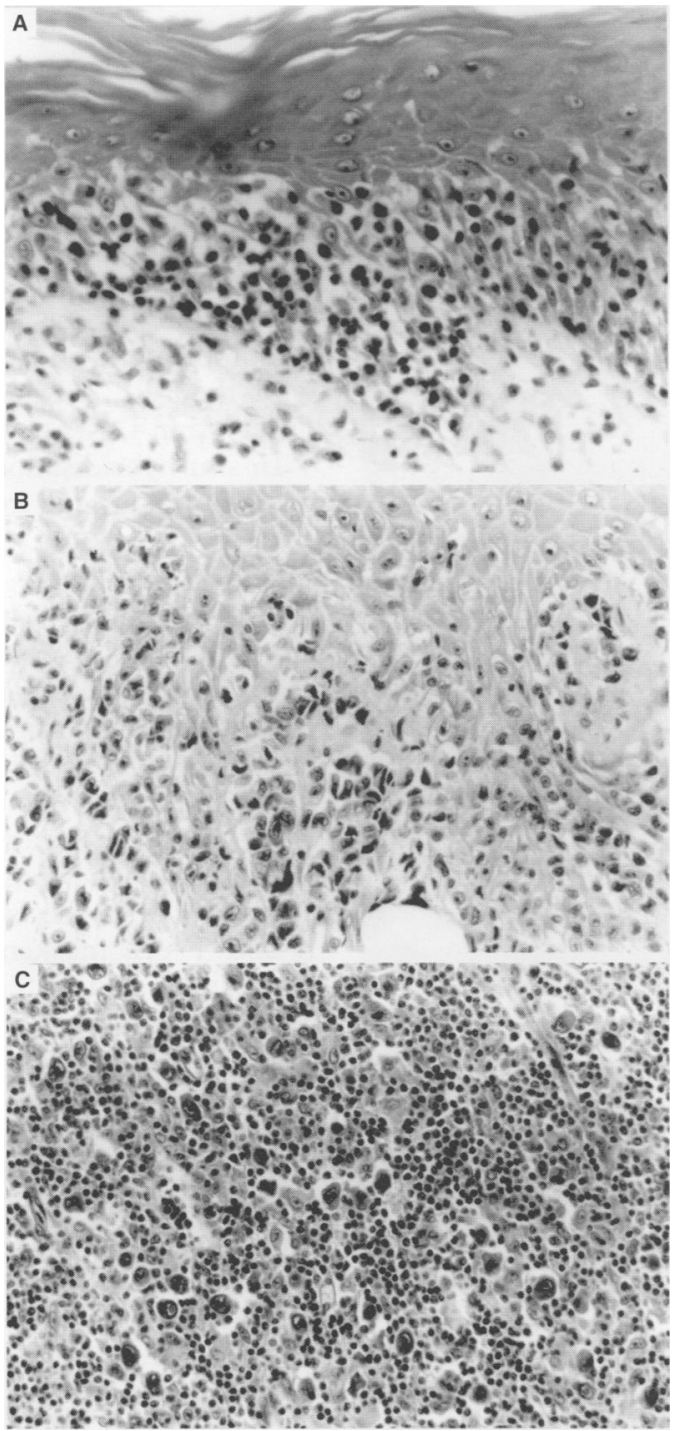

Figure 2 (A) Histology of a cutaneous plaque from case 1 , showing Sezary cells and Pautrier's microabcesses (×320). (B) Morphology of a LCL lesion from the same patient. Note large cells with cerebriform nuclei $(\times 400)$. (C) Hodgkin's disease lesion of NS subtype with abundant $R S$ cells, including variants.

preservation of a large number of leucocyte differentiation antigens and diagnostic morphological detail.

\section{IMMUNOHISTOCHEMISTRY AND IN SITU} HYBRIDISATION

Immunohistochemistry was carried out on frozen sections using the alkaline phosphataseanti-alkaline phosphatase technique as described by Cordell et al. ${ }^{8}$ Paraffin wax (or paraplast in the case of the ModAMeX method) sections were stained immunohis- tochemically using the horseradish peroxidase conjugated Streptavidin-biotin complex (Dako, Glostrup, Denmark) as described by the manufacturer.

To ascertain the sensitivity of the assay for detecting gene rearrangements, the degree of infiltration by neoplastic cells was calculated as the mean of the total frequency of ReedSternberg (RS) cells, including variants, counted in three randomly chosen fields $(\times 1000) .{ }^{9}$ Using this method, patients can be divided into one of three groups: in group A, the patients exhibited a mean of greater than 25 tumour cells/high power field; group B, 10-25 tumour cells; and group C, < 10 tumour cells. The method is approximate but is generally expected to yield a good result. Both patients in the present study met the criteria for inclusion in group A.

The presence/absence of Epstein-Barr virus (EBV) was detected by in situ hybridisation, as described previously. ${ }^{10}$

\section{DNA ISOLATION AND POLYMERASE CHAIN} REACTION (PCR)

DNA was extracted from fresh frozen tissues as described elsewhere ${ }^{10}$ and amplified using a standard protocol and semi-nested PCR. ${ }^{11}$ Gene rearrangements were detected using primers directed against the J region and FR2 and FR3 of the $\mathrm{V}$ region of the immunoglobulin heavy chain gene, or the $\mathrm{T}$ cell receptor (TCR) $\gamma$ chain gene. ${ }^{11}$ The primers used in both PCR assays were as described by Trainor et al. ${ }^{11}$ PCR products were vizualised on 6 or $8 \%$ polyacrylamide gels stained with ethidium bromide and viewed under ultraviolet light. The sensitivity of the PCR assay was assessed by mixing doubling dilutions of DNA from a $B$ lymphoma cell line (Deglis) ${ }^{12}$ and the CEM and HSB2 T lymphoma cell lines, positive for $\gamma 1$ and $\gamma 2$, respectively, with DNA from normal polyclonal blood lymphocytes and noting the lowest dilution at which the monoclonal band could still be observed. ${ }^{11}$ The lower limits of detection for a clonal rearrangement were as follows: $2 \%$ for FR2; 5\% for FR3; $10 \%$ for $\gamma 1$; and $1 \%$ for $\gamma 2$ (fig 1 ).

\section{Results}

The cutaneous lesions were histologically characteristic of mycosis fungoides in both patients (fig $2 \mathrm{~A}$ ). In case 1 , however, about $10 \%$ of the cells were large, with hyperchromatic and irregularly shaped nuclei, very similar to those found in LCL, which the patient subsequently developed (fig $2 \mathrm{~B}$ ).

\section{CASE 1}

Tumour cells from the mycosis fungoides and LCL lesions had the following phenotype: pan B (CD19, CD20, CD22) negative, CD2+, CD3+, CD5-, CD7-, TCR $\beta+$, CD4+, $\mathrm{CD} 25+$. In the mycosis fungoides lesions, only a few cells stained positively with antibodies directed against CD30 and epithelial membrane antigen (EMA); numerous cells were CD30+, EMA+ in the LCL lesions. Hodgkin's disease lesions were of the nodular sclerosis (NS) subtype with fairly numerous RS cells 

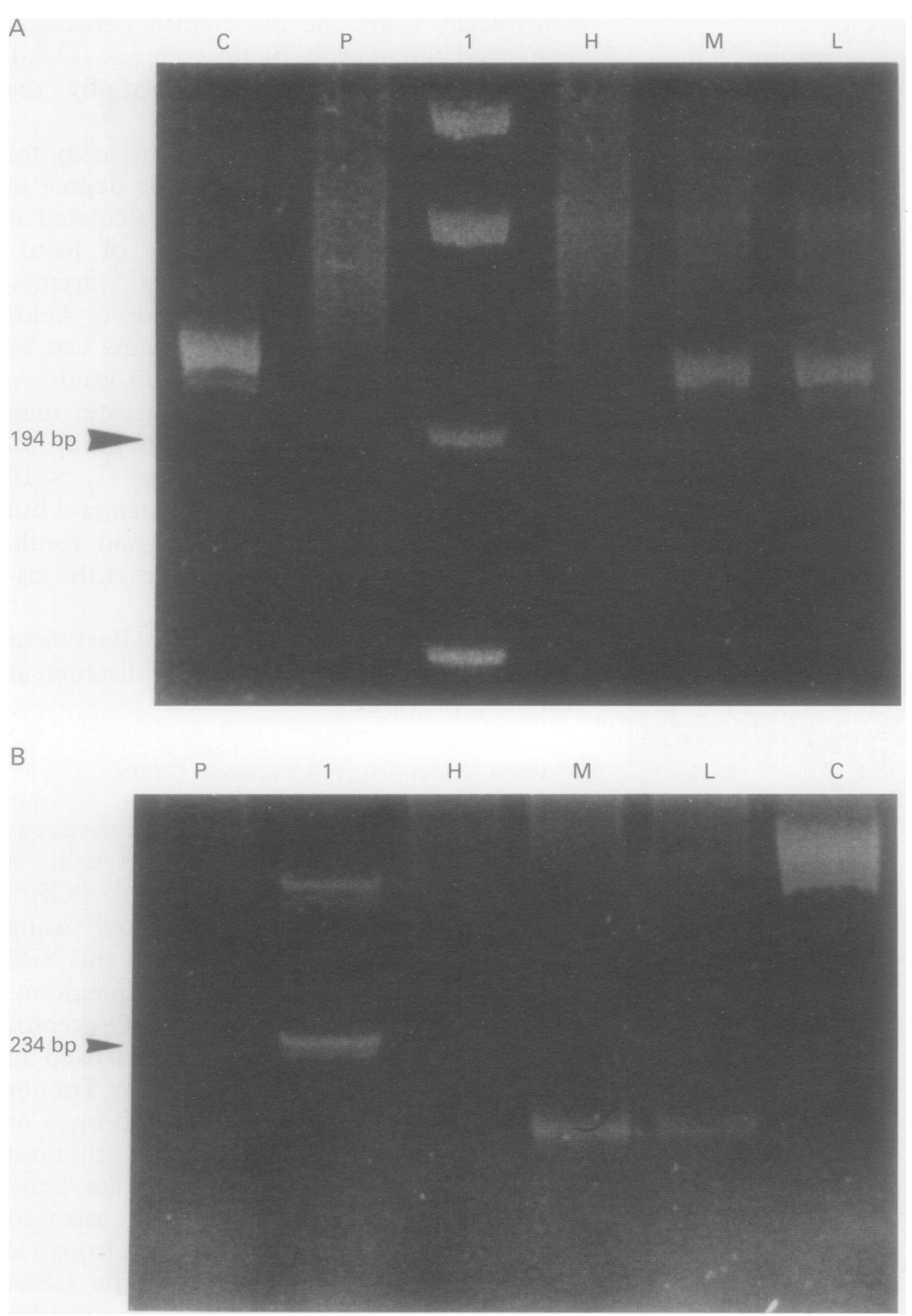

Figure 3 (A) PCR products produced by amplifying DNA from case 1 with the $\gamma 1$ primer set. Lane 1, molecular weight markers; lane $P$, negative control (polyclonal control); lane $M$, $D N A$ from mycosis fungoides cells; lane $L, D N A$ from $L C L$ cells; lane $H, D N A$ from Hodgkin's cells; lane C, monoclonal control (CEM T lymphoma cell line). (B) PCR products produced by amplifying DNA with the FR2 primer set. Lane P, negative control; lane 1, molecular weight marker; lane $H, D N A$ from Hodgkin's cells; lane $M, D N A$ from mycosis fungoides cells, lane $L, D N A$ from $L C L$ cells; lane $C$, clonal control (Deglis $B$ lymphoma cell line). Note that the immunoglobulin heavy chain genes are clonally rearranged in both mycosis fungoides and LCL cells and that the band produced is of the same size. DNA extracted from Hodgkin's cells was not clonally amplified.

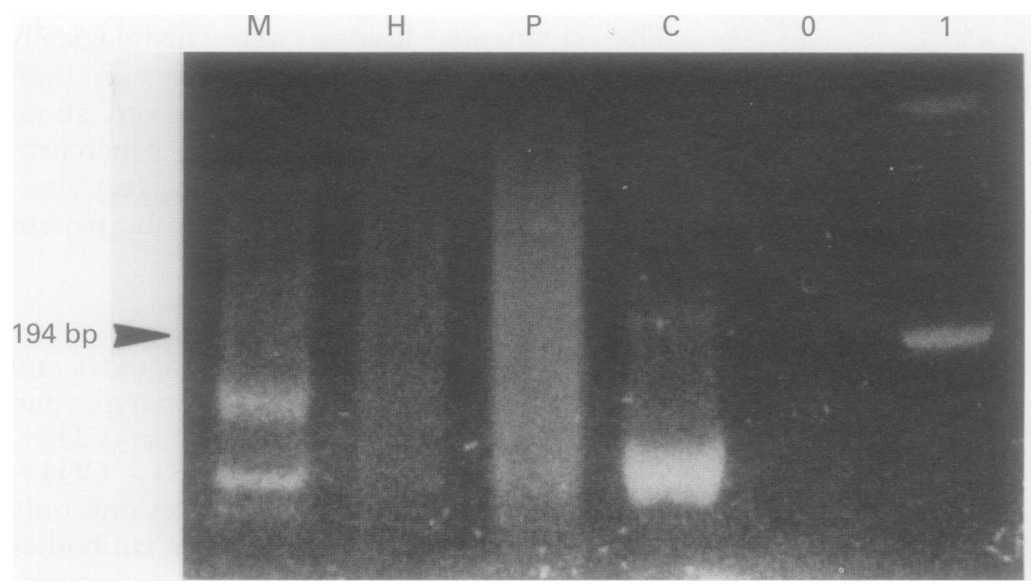

Figure $4 P C R$ products by amplifying DNA from case 2 with $\gamma 2$ primer set. Lane $M$, $D N A$ from mycosis fungoides cells; lane $H, D N A$ from Hodgkin's cells; lane $C$, clonal control (HSB2 T lymphoma cell line). Note the lack of signal in lanes $H, P$ (polyclonal control) and 0 (blank: no DNA template present). (group A) (fig 2C), and exhibited a null phenotype (pan-B-, pan T-), CD15+, CD30+, and with a few cells positive for EMA. The RS cells were negative for EBV latent membrane protein 1 (LMP-1).

PCR revealed TCR $\gamma(\gamma 1, \gamma 2)$ chain gene rearrangements in DNA from mycosis fungoides and LCL cells. Rearrangements were not observed in the Hodgkin's cells (fig 3A). Immunoglobulin heavy chain genes were clonally rearranged in both mycosis fungoides and LCL (FR2+, FR3-) cells but a polyclonal banding pattern was observed with DNA from Hodgkin's cells (fig 3B).

CASE 2

Mycosis fungoides tumour cells were pan B negative, $\mathrm{CD} 2+, \mathrm{CD} 3+, \mathrm{CD} 5+, \mathrm{CD} 7-$, TCR $\beta+, C D 4+$. Hodgkin's cells (NS subtype) in this patient also exhibited the null phenotype and again a few cells were EMA+.

TCR $\gamma$ chain gene rearrangements were detected in mycosis fungoides cells with the $\gamma_{2}$ set of primers only. No clonal amplification with the FR2, FR3, $\gamma 1$, and $\gamma 2$ primers was observed in DNA from Hodgkin's cells (fig 4).

In situ hybridisation confirmed the absence of EBV in all tissue from both patients.

\section{Discussion}

These results suggest that mycosis fungoides and Hodgkin's disease are not derived from the same tumour cell clone in these two patients. Firstly, the phenotypic transformation of mycosis fungoides neoplastic T cells to RS cells is unlikely because this would involve the loss of all $T$ cell lineage antigens associated with the former, and the gain of activation antigens associated with the latter. Also, although both $B$ and $T$ cell markers have been detected in Hodgkin's and RS cells, these cells are generally thought to be derived from B cells. ${ }^{13}{ }^{14}$ Secondly, if the Hodgkin's cells in our two patients were clonally derived from mycosis fungoides cells, then the gene rearrangements present in the latter would be expected to persist in the former. This was not the case in the present study. Similar results have been reported by Daus et $a l^{15}$, who demonstrated that Hodgkin's and RS cells do not harbour TCR gene rearrangements.

Transformation of mycosis fungoides to LCL has been reported previously ${ }^{16}$ and our results suggest that, in case 1 , the same clone was involved because of identical phenotypic and TCR $\gamma$ rearrangements. It would have been necessary to sequence the area of the TCR gene harbouring the rearrangement in these tumours to confirm identical clonality, but as the mycosis fungoides and LCL cells also harboured the same immunoglobulin heavy chain gene clonal rearrangements (FR2,+ FR3-), it is most likely that these cells were derived from the same clone. IgH gene rearrangements have also been found in patients with $T$ cell lymphoma. ${ }^{17}$ Our results are in keeping with the report by Wood et $a l,{ }^{18}$ who demonstrated that mycosis fungoides and its high grade lymphoma counterpart were derived from the same $T$ cell clone (with the same sequence at 
the TCR $\beta$ chain gene junction). Our data do not support the postulate of Davis et al that lymphomatoid papulosis, mycosis fungoides and Hodgkin's disease share the same clonal origin, although all three conditions can occur in the same patient. Hodgkin's disease in the cases reported here seems to have been a second neoplasm and was not related to EBV infection. It is possible that the development of Hodgkin's disease was related to treatment of mycosis fungoides, but the factors underlying the concomitant occurrence of these two conditions have yet to be elucidated.

This work was supported by grants from La Fédération des Centres de Lutte Contre le Cancer and Délégation à la Recherche Clinique.

We would like to thank Mr Daniel Roda for help with PCR studies and Professor S M Chittal, St John's, Newfoundland, Canada, for his comments on the manuscript.

1 Block JB, Edgcomb J, Eisen A. Mycosis fungoides: Natural history and aspects of its relationship to other malignant lymphoma. Am $₹$ Med 1963;34:228-35.

2 Chan WC, Griem ML, Grzea PN, Freel RJ, Variakojis D. Mycosis fungoides and Hodgkin's disease occurring in the same patient. Cancer 1979;44:1408-13.

3 Simrell CR, Boccia RV, Longo DL, Jaffe ES. Coexisting Hodgkin's disease and mycosis fungoides. Immunohistochemical proof of its existence. Arch Pathol Lab Med 1986;110:1029-34.

4 Lipa M, Kunynetz R, Pawlowski D, Kerbel G, Haberman H. The occurrence of mycosis fungoides in two patients with preexisting Hodgkin's disease. Arch Dermatol 1982; 118:563-7.

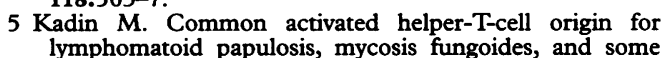
types of Hodgkin's disease. Lancet 1985;ii:864-5.

6 Davis TH, Morton CC, Miller-Cassman R, Balk SP, Kadin ME. Hodgkin's disease, lymphomatoid papulosis, and cutaneous T-cell lymphoma derived from a common T-cell cutaneous T-cell ymphoma derived from

7 Delsol G, Chittal SM, Brousset P, Caverivière P, Roda D, Mazerolles C, et al. Immunohistochemical demonstration of leucocyte differentiation antigens on paraffin sections using a modified AMeX (ModAMeX) method. Histopathology 1989;15:461-71.

8 Cordell JL, Falini B, Erber WN, Ghosh AK, Abdulaziz Z, MacDonald S, et al. Immunoenzymatic labelling of monoclonal antibodies using immune complexes of alkaline clonal antibodies using immune complexes of alkaline phosphatase and anti-alkaline phosphatase (APAAP

plexes). F Histochem Cytochem 1984;32:219-29.
9 Knecht H, Odermatt BF, Bachmann E, Teixeira S, Sahli R, Hayoz $\mathrm{P}$, et al. Frequent detection of Epstein-Barr virus DNA by the polymerase chain reaction in lymph node biopsies from patients with Hodgkin's disease without evidence of B- or T-cell clonality. Blood 1991;78:760-7.

10 Brousset P, Meggetto F, Chittal S, Bibeau F, Arnaud J, Rubin B, et al. Assessment of the methods for the detection of Epstein-Barr nucleic acids and related gene products in Hodgkin's disease. Lab Invest 1993;69:483-90.

11 Trainor KJ, Brisco MJ, Wan JH, Neoh S, Grist S, Morley AA. Gene rearrangement in B- and T-lymphoproliferative disease by the polymerase chain reaction. Blood 1991; 78:192-6.

12 Al Saati T, Delécluze HJ, Chittal S, Brousset P, Magaud JP, Dastugue N, et al. A novel lymphoma cell line (Deglis) with dual $\mathrm{B} / \mathrm{T}$ phenotype and gene rearrangements and containing Esptein-Barr virus genomes. Blood 1992; 80:209-6.

13 Orazi A, Bingdong J, Lee CH, English GW, Cattoretti G, John $\mathrm{K}$, et al. Correlation between presence of clonal rearrangements of immunoglobulin heavy chain genes and B-cell antigen expression in Hodgkin's disease. Am $\mathcal{F}$ Clin Pathol 1995;104:413-18.

14 Kamel OW, Chan PP, Hsu FJ, Dolezal MV, Warnke RA, Van de Rijn M. Clonal VDJ recombination of the immunoglobulin heavy chain gene by PCR in classical Hodgkin's disease. Am f Clin Pathol 1995;104:419-23.

15 Daus H, Trumper L, Roth J, von Bonin F, Gause A, Pfreunschuh $M$. Hodgkin and Reed-Sternberg cells do not carry T-cell receptor $\gamma$ gene rearrangements: evidence from single cell polymerase chain reaction examination. Blood 1995;85: 1590-5.

16 Salhany KE, Cousar JB, Greer JP, Casey TT, Fields JP, Collins RD. Transformation of cutaneous T-cell lymphoma to large cell lymphoma: a clinicopathologic and immunophenotypic study. Am f Pathol 1988;132:265-77.

17 Pelicci PG, Knowles D, Dalla-Favera R. Lymphoid tumors displaying rearrangements of both immunoglobulin and T-cell receptor genes. $\mathcal{F}$ Exp Med 1985;162:1015-19.

18 Wood GS, Bahler DW, Hope RT, Warnke RA, Sklar J, Levy $R$. Transformation of mycosis fungoides: T-cell receptor $\beta$ gene analysis demonstrated a common clonal origin for plaque-type tumor mycosis fungoides and CD $30+$ large plaque-type tumor mycosis fungoides and CD30+ large
cell lymphoma. F Invest Dermatol 1993;101:296-300. 